\title{
In Vitro Assay and Study Interaction of Uncaria gambir (Hunter) Roxb. as Anti-fibrotic Activity Against A549 Cell Line
}

\author{
Desdiani Desdiani ${ }^{1, *}$, Iris Rengganis ${ }^{2}$, Samsuridjal Djauzi ${ }^{2}$, Agus Setiyono ${ }^{3}$, Mohamad Sadikin ${ }^{4}$, Sri Widia A. \\ Jusman ${ }^{4}$, Nuryati Chairani Siregar ${ }^{5}$, Suradi ${ }^{6}$, Putri C. Eyanoer ${ }^{7}$, Fadilah Fadilah ${ }^{8, *}$
}

Desdiani Desdiani ${ }^{1}, *$, Iris Rengganis ${ }^{2}$, Samsuridjal Djauzi ${ }^{2}$, Agus Setiyono ${ }^{3}$, Mohamad Sadikin ${ }^{4}$, Sri Widia A. Jusman ${ }^{4}$, Nuryati Chairani Siregar ${ }^{5}$, Suradi ${ }^{6}$, Putri C. Eyanoer ${ }^{7}$, Fadilah Fadilah $^{8, *}$

${ }^{1}$ Faculty of Medicine, Universitas Sultan Ageng Tirtayasa, Cilegon, Banten, Indonesia ${ }^{2}$ Department of Internal Medicine, Faculty of Medicine, University of Indonesia, Jakarta, INDONESIA.

${ }^{3}$ Faculty of Veterinary Medicine IPB, Bogor, INDONESIA.

${ }^{4}$ Department Biochemistry and Molecular Biology, Faculty of Medicine, University of Indonesia, Depok, INDONESIA.

${ }^{5}$ Department Anatomical Pathology, Faculty of medicine, University of Indonesia, Jakarta, INDONESIA.

${ }^{6}$ Department of Pulmonology and Respiratory Medicine, Faculty of medicine, Universitas Sebelas Maret, Surakarta, INDONESIA. ${ }^{7}$ Department of Community and Preventive Medicine, Universitas Sumatera Utara ${ }^{8}$ Department of Medical Chemistry, Faculty of medicine, University of Indonesia Bioinformatics Core Facilities, Indonesian Medical Education and Research Institute (IMERI), Jakarta, INDONESIA.

\section{Correspondence}

Desdiani Desdiani

Doctoral Degree Student of Faculty of Medicine, University of Indonesia; Faculty of Medicine University of Sultan Ageng

Tirtayasa, Cilegon, Banten, INDONESIA.

E-mail: desdiani@ymail.com

\section{Fadilah Fadilah}

Department of Medical Chemistry, Faculty of medicine, University of Indonesia;

Bioinformatics Core Facilities, Indonesian Medical Education and Research Institute (IMERI), Jakarta, INDONESIA.

E-mail: fadilah81@gmail.com

History

- Submission Date: 28-05-2020;

- Review completed: 22-06-2020;

- Accepted Date: 01-07-2020

DOI : 10.5530/pj.2020.12.172

Article Available online http://www.phcogj.com/v12/i6

Copyright

(C) 2020 Phcogj.Com. This is an openaccess article distributed under the term of the Creative Commons Attribution 4.0 International license.

\section{ABSTRACT}

Aim: The aim of this study is to finding inhibitor potential from several compounds in gambir plant by using in vitro MTT assay and study interaction with molecular docking. The interaction of amino acids on the binding site with substances in the gambir plant was analyzed to determine its potential as a herbal-based therapy candidate for pulmonary fibrosis. Material and Methods: Protein target using TGF $\beta 1$ and NF-KB and compounds from gambir plant ((+)-Catechin. Epigallocatechin gallate, (+)-Epicatechin, Gambiriin A1, Gambiriin A2, Gambiriin B1, Gambiriin B2, Gambiriin C, Procyanidin B1, Procyanidin B3). Result: The results from docking analysis observed that compounds from gambir fruit contain anti-fibrotic activity which act by inhibiting DNA transcription of NF- $\mathrm{kB}$ and TGF- $\beta 1$ receptors. The compound Procyanidin B3, an essential amino acid, contains a hydrogen bond with the greatest NF- $\mathrm{KB}$ inhibitory activity on Gly214 and Lys337. Compounds from Uncaria gambir (Hunter) Roxb. can be an inhibitor to TGF $\beta 1$, all the compounds are on the active site of TGF $\beta 1$, and use native ligand which is an inhibitor of TGF $\beta 1$ (Naphtyridine). The positive compound catechin has the highest inhibitory activity. Gambiriin B1 and Gambiriin A2 are the most identical compounds with similar affinity binding value. Uncaria gambir (Hunter) Roxb. is already a proven antifibrotic which is further confirmed by (IC50: 19,255 $\pm 1.08 \mu \mathrm{g} / \mathrm{ml}, \mathrm{p}<0.05$ ) in A549 cell line. Conclusion: The results demonstrated that Gambiriin have cytotoxic effects and was found potentially as anti-fibrotic by MTT assay and in silico evaluation.

Key words: Gambiriin compounds, Inhibitor of p50 NF-kB, Molecular docking, Pulmonary fibrosis, TGF- $\beta 1$ receptors.

\section{INTRODUCTION}

Pulmonary fibrosis is a condition of scar tissue formation that involves infiltration of inflammatory cells, fibroblasts proliferation, reactive oxygen species (ROS), and excessive accumulation of extracellular matrices to the pulmonary parenchymal tissues and can cause dysfunction to pulmonary function. ${ }^{1,2}$ The appropriate treatment for pulmonary fibrosis is still a challenge. The use of chemical substances effective for pulmonary fibrosis treatment does not always provide consistent significant results due to adverse events. ${ }^{3}$ Several methods to prevent and reduce pulmonary fibrosis have been widely conducted using drugs that interact with TGF $\beta$ and have the potential to activate anti-fibrosis. The drugs were tranilast (inhibit the activity and secretion of TGF $\beta$ ), losartan (TGF $\beta$ induction blockade), PPAR-y agonists (damaging Smad3 signal transduction), pirfenidone (inhibit the production of TGF $\beta$ ), and halofuginone). ${ }^{3}$ The effectivity limitations of these chemical substances in overcoming pulmonary fibrosis lead to the utilization of natural ingredients as an alternative.

Anti-fibrotic drugs such as Pyfenidone were developed for the treatment of idiopathic pulmonary fibrosis. Because fibroblast activities in inflammatory conditions have the same characteristics as cancer-related fibroblasts that actively contribute to phenotype, the search for antifibrotic drugs can be through a repurposed approach as an anti-cancer drug. ${ }^{4}$ Furthermore, it has been shown that drug such as pirfenidone can inhibits proliferation, and epithelial-mesenchymal transition of a human epithelial cell line, ${ }^{5}$ disrupted tumorstromal interactions in pancreatic cancer, ${ }^{6}$ and inhibited TGF $\beta$ linduced overexpression of collagen type I in A549 cells. ${ }^{7}$

TGF- $\beta$ is involved in pulmonary fibrosis promoting progression by both autocrine and paracrine mechanisms. ${ }^{1}$ Studies in adenovirus transfected or transgenic revealed that TGF- $\beta$ contributed to HSC activation and fibrotic damage, and that blocking TGF- $\beta$ signalling inhibited the fibrotic process., ${ }^{2,3}$ TGF- $\beta 1 /$ Smads signalling is required for fibrosis. ${ }^{4}$

However, there is lack in studies addressing the exact molecular mechanism behind this effect, which is a common challenge in the natural products research. Therefore, molecular docking studies can explain the interactions between phytochemicals and the molecular targets, which could be a successful approach to develop new drugs.

Gambir or Uncaria gambir (Hunter) Roxb. is a specific local plant in South East Asia, especially Indonesia and Malaysia. Gambir contains polyphenol substances with its main component of

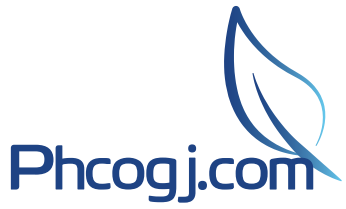

Cite this article: Desdiani D, Rengganis I, Djauzi S, Setiyono A, Sadikin M, Jusman SWA, et al In Vitro Assay and Study Interaction of Uncaria gambir (Hunter) Roxb. as Anti-fibrotic Activity Against A549 Cell Line. Pharmacogn J. 2020;12(6):1232-40. 
flavonoid (+)-catechin comprises of $40-80 \%$ dry extract weight, and (-)-epicatechin $1.5 \%$, procyanidin $\mathrm{B} 1$, procyanidin $\mathrm{B} 3$, and gambiriin each comprises of $1 \%$. The most commonly used chemical substance of gambir is catechin and tannin, which is the polymer form of catechin. ${ }^{7,8}$ Gambir has antioxidant properties, can inhibit the activation of NFkB by suppressing the formation of collagen, TIMP-1 through in vivo fibrolysis, and fibropreventive mechanism in the fibrotic. The main component of Gambir is a flavonoid (+)-catechin, which comprises of $40-80 \%$ of dried sap and had been proven to have a strong antioxidant activity, almost comparable to vitamin $\mathrm{C}$ in vitro, and inhibits the activation of $\mathrm{NFKB}$ in vivo. Thus, enables its role as anti-fibrotic therapy in the lungs and pleura.

Structure-based drug design (SBDD) is a chemical computation method which utilizes the information from target protein structures to determine protein active site that bonds with substances. Based on the active site prediction, the expected substance can be designed to attach with the target protein and provide biological activity. Using the information of target structure and ligand physicochemical property, screening of interaction between known active substances (ligand) on the prediction of protein active site can be performed. Based on the obtained information, this new substance design is expected to be more potent than the available substances. One of the commonly used SBDD methods is molecular docking. ${ }^{9}$

In silico examination there is a term for an experiment or an exam conducted by a computer simulation method. The in silico test has become a method used to initiate the discovery of new compounds and to increase efficiency in optimizing the activity of parent compounds. The purpose of psycho exams is to predict, give hypotheses, make new discoveries or new advances in medicine and therapy. One of the in silico tests was carried out by the molecular docking method of a prospective compound of a drug compound with the selected receptor. Docking is an attempt to align between ligands which are small molecules into receptors which are large protein molecules, by paying attention to the properties of both. ${ }^{10}$ This study conducted in silico testing of the molecular docking method of binding affinity results of molecular docking and the interaction of amino acids on the binding site with substances in the gambir plant was analyzed to determine its potential as a herbal-based therapy candidate for pulmonary fibrosis.

\section{MATERIALS AND METHODS}

\section{Computational methods}

All computational studies to perform the in sillico experiments were carried out using MacBook Air with operating system Mac OS High Sierra 10.13.3, processor Intel Core i5 1.8GHz, RAM 8 GB, $1600 \mathrm{MHz}$ DDR3. Marvin Sketch to draw ligand structure in 2 and 3 dimensions. AutoDockVina for docking process. AutoDockTools for docking result analysis and 3D visualization of the ligand-receptor complex. LigPlus for analysis of residual amino acids of the ligand-receptor complex in $2 \mathrm{D}$.

\section{Druglikeness}

DruLiTo is open source software to can calculate different molecular properties and screen the molecules based on drug likeness rules using 'The Lipinski rule of five'.

\section{Protein preparation}

Structures of protein targets (+)-Catechin. Epigallocatechin gallate, (+)-Epicatechin, Gambiriin A1, Gambiriin A2, Gambiriin B1, Gambiriin B2, Gambiriin C, Procyanidin B1, Procyanidin B3.

\section{Receptor preparation}

Download receptor from www.rcsb.org in .pdb format. Separate chain receptor and ligand. Eliminate water using delete water in Autodock software. Add hydrogen atom (polar only) and merge non-polar. Add Gasteiger charges on the receptor. Save file in .pdbqt.

\section{Ligand preparation}

Separate the original PDB ligand from a receptor-ligand complex (specific to ligands from receptor-ligand PDB complex). Draw nine substances in .pdb format using Marvin Sketch.

\section{Docking method validation}

Conduct docking on PDB ligand using the optimization of grid box size and center grid position. Choose the optimal size of the grid box and grid center by determining the result of docking.

\section{Docking and docking result analysis}

Make 1 folder containing protein and ligand in.pdbqt format. Configure docking (protein file name, ligand file name, grid box coordinate, grid box size, output file name, and model numbers produced) Implement docking using AutodockVina through the Terminal. The best docking model from docking file output (.pdbqt) was separated using vina_split. Analysis and visualization of the ligand-receptor complex through Ligplus.

\section{Preparation of extract}

The fresh fruits of Uncaria gambir (Hunter) Roxb were washed under running water and shade dried. Finely powdered by mechanical grinder and extracted with $90 \%$ ethanol by maseration maintaining at room temperature $3 \times 24$ houre. Evaporated the solvent by rotary evaporator and brownish gummy exudates were obtained. The crude Uncaria gambir (Hunter) Roxb extract was used for citotoxicity properties. The fraction yield of extract Uncaria gambir (Hunter) Roxb was calculated by using the formula.

$$
\% \text { yield }=\frac{\text { weight of crude extract }}{\text { weight of raw material }} \times 100
$$

The fraction yield of ethanolic extract of Uncaria gambir (Hunter) Roxb was found to be $7.15 \% \mathrm{w} / \mathrm{w}$.

\section{Total phenol content}

The estimation of the total phenol content was done by using folin ciocalteu reagent method. $2.5 \mathrm{ml}$ of saturated $\mathrm{Na}_{2} \mathrm{CO}_{3}$ was added to the pre incubated $0.5 \mathrm{ml}$ of EOEt extract with $0.1 \mathrm{ml}$ of folin ciocalteu reagent $(0.5 \mathrm{~N})$ for $15 \mathrm{~min}$ in optimum temperature. Measure the absorbance at $760 \mathrm{~nm}$ using quercetin as standard. The total phenol content was uttered as standard equivalent $(\mathrm{mg} / \mathrm{g})$.

\section{Total flavonoid content}

The total flavonoid content was estimated by using Aluminum chloride method. The mixture $(3.0 \mathrm{ml})$ contains $1.0 \mathrm{ml}$ extract of Uncaria gambir, $0.5 \mathrm{ml}$ of aluminum chloride (1.2\%) and $0.5 \mathrm{ml}$ of $120 \mathrm{mM}$ potassium acetate were pre-incubated in room temperature for $30 \mathrm{~min}$ and at 415 $\mathrm{nm}$ the absorbance was measured using catechin as standard. The total flavonoid content was uttered in terms of standard equivalent $(\mathrm{mg} / \mathrm{g})$.

\section{MTT assay}

Eagle's Minimum Essential Medium (EMEM) supplemented with 10\% FBS; DMEM and RPMI1640 are also alternatives that work well. Aspirate and add fresh culture medium every 2-3 days. A549 cell doubling time is 48 hours. To passage cells, rinse cell monolayer with $1 \mathrm{x}$ 
PBS twice and add pre-warmed $\left(37^{\circ} \mathrm{C}\right) 0.05 \%$ Trypsin-EDTA solution to cover the bottom of the flask; incubate for $5-7$ minutes. As cells detach, neutralize the Trypsin by adding $4 \mathrm{x}$ volume of complete growth medium with $10 \%$ FBS and gently resuspend the cells by pipetting

To avoid clumping do not agitate the cells by shaking the flask while waiting for detachment. Split cells 1:4 every 3 days or 1:8 every 6 days. Cultures should be incubated at $37^{\circ} \mathrm{C}$ in a humidified atmosphere with 5\% CO2. If cells are difficult to detach the suggestions are cellto-cell junctions are tight due to cell growth being 100\% confluent and dissociation agent cannot reach cell interface; subculture cells before confluent. Use higher concentration of dissociation agent; incubate flask at $37^{\circ} \mathrm{C}$ to increase enzymatic activity. Wash flask twice with sterile $1 \mathrm{x}$ PBS prior to addition of the dissociation agent.

\section{RESULTS AND DISCUSSION}

In silico pharmacokinetic properties and toxicities were predicted using ADME property explorer using DruLiTo is an open source virtual screening tool. This calculation is based on the various drug-likeness rules like Lipinski's rule. Drug-likeness rules like Lipinski's rule were predicted of chemical constituents from extract of gambir analysis by online software at http://www.niper.gov.in/pi_dev_tools/DruLiToWeb/ DruLiTo_index.html. Results of ADME analysis are shown in Table 1.

Drug likeness can be estimated for any molecule, and does not evaluate the actual specific effect that the drug achieves (biological activity). Simple rules are not always accurate and may unnecessarily limit the chemical space to search: many best-selling drugs have features that cause them to score low on various drug-likeness indices. It is estimated from the molecular structure before the substance is even synthesized and tested. A druglike molecule has properties such as Solubility in both water and fat, Potency at the biological target, and Ligand efficiency and lipophilic efficiency.

Docking is an attempt to align between ligands which are small molecules into receptors which are large protein molecules, by paying attention to the properties of both. Result of docking approach with ligand from gambir extract with NF- $\kappa \mathrm{B}$ p50 and TGF- $\beta 1$ :

\section{Substance docking with NF-KB p50}

All substances studied were tethered to the binding site of the receptor (ID PDB: 1SVC) using AutodockVina. The grids were prepared for each protein with a similar center and border-box size set at $0.375 \AA$ distance, with a grid box size of $60 \times 60 \times 60$. The grid center coordinate was $(x=37.569 ; y=24.716 ; z=38.430)$ (Figure 1).

$\mathrm{NF}-\kappa \mathrm{B}$ is the regulation center of the stress response, activated by various stress conditions, including physical and oxidative stress. From the docking results, the substances acted in DNA transcription inhibition of NF- $\mathrm{KB}$. Based on molecular docking results, three compounds from gambir plant: gambiriin $\mathrm{A} 1$, procyanidin $\mathrm{B} 1$ and procyanidin $\mathrm{B} 3$ have the best binding affinity score $-8.4 ;-8.4$; and $-8.6 \mathrm{kcal} / \mathrm{mol}$ (Table 2 ).

Procyanidin B3 had a hydrogen bond with the highest inhibitory activity (Figure 2). Residuals interacted with Procyanidin B3, Procyanidin $\mathrm{B} 1$ and Gambiriin A1 ligands were in the IPT domain of NF- $\kappa B$ transcription factor (251-352), GRR area (374-396), and interaction domain of CFLAR/CASP8 and FADD-like apoptosis regulator (437970). These three ligands had similar amino acid bonding on Gly214 and Lys337. The three ligands in successive order were Procyanidin B3, Procyanidin B1, and Gambiriin A1 had 9, 11, and 12 interactions with amino acid residue (Table 3 ). This showed that even though Procyanidin B3 had the fewest amino acid interaction, the interacting amino acid was an essential amino acid important to determine the binding affinity. The interaction of substances in the Gambir plant is expected to inhibit the transcription of NF- $\mathrm{KB}$.

\section{Docking of substance with TGF- $\beta 1$}

All substances were attached to the receptor binding site (PDB ID: 1VJY) using AutodockVina. The grids were prepared for each protein with a similar center and border-box size determined at $0.375 \AA$

Table 1: Druglikeness Lipinski's rule of chemical constituents of Uncaria gambir (Hunter) Roxb.

\begin{tabular}{ccccc}
\hline Compounds name & $\begin{array}{c}\text { Molecular Weight } \\
\text { g/mol }\end{array}$ & $\begin{array}{c}\text { TPSA } \\
\text { A }^{2}\end{array}$ & LogP & Lipinski \\
\hline (+)-Catechin & 322.74 & 86.99 & 1.70 & $\mathrm{Y}$ \\
Epigallocatechin gallate & 299.32 & 81.78 & 2.33 & $\mathrm{Y}$ \\
(+)-Epicatechin & 285.29 & 92.78 & 1.64 & $\mathrm{Y}$ \\
Gambiriin A1 & 316.31 & 96.22 & 2.66 & $\mathrm{Y}$ \\
Gambiriin A2 & 368.77 & 116.45 & 2.33 & $\mathrm{Y}$ \\
Gambiriin B1 & 344.36 & 85.22 & 3.20 & $\mathrm{Y}$ \\
Gambiriin B2 & 562.53 & 200.52 & 3.44 & $\mathrm{Y}$ \\
Gambiriin C & 562.53 & 200.52 & 3.07 & $\mathrm{Y}$ \\
Procyanidin B1 & 578.53 & 220.75 & 2.58 & $\mathrm{Y}$ \\
Procyanidin B3 & 578.53 & 220.75 & 2.58 & $\mathrm{Y}$ \\
\hline
\end{tabular}

Table 2: Binding affinity score from docking gambir compounds with p50 NF-KB.

\begin{tabular}{ccc}
\hline No & Compounds & $\Delta \mathrm{G}(\mathrm{kcal} / \mathrm{mol})$ \\
\hline 1 & $(+)$-Catechin & -7.0 \\
2 & Epigallocatechin gallate & -7.2 \\
3 & $(+)$-Epicatechin & -6.5 \\
$\mathbf{4}$ & Gambiriin A1 & $-\mathbf{8 . 4}$ \\
5 & Gambiriin A2 & -8.4 \\
6 & Gambiriin B1 & $-7,8$ \\
7 & Gambiriin B2 & -8.3 \\
8 & Gambiriin C & -8.2 \\
$\mathbf{9}$ & Procyanidin B1 & $\mathbf{- 8 . 4}$ \\
$\mathbf{1 0}$ & Procyanidin B3 & $\mathbf{- 8 . 6}$ \\
\hline
\end{tabular}




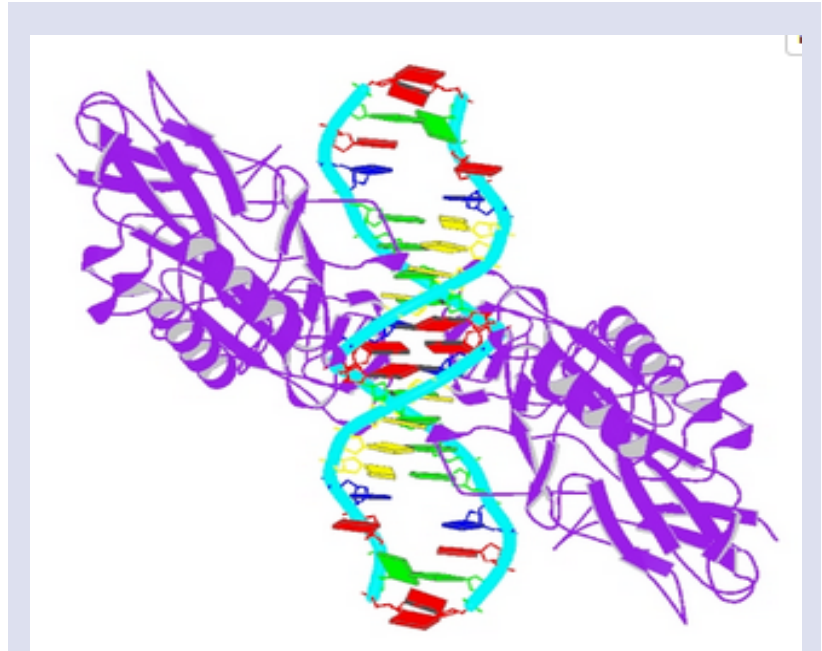

Figure 1: 3D structure of NF-KB p50 homodimer (PDB ID: 1SVC).
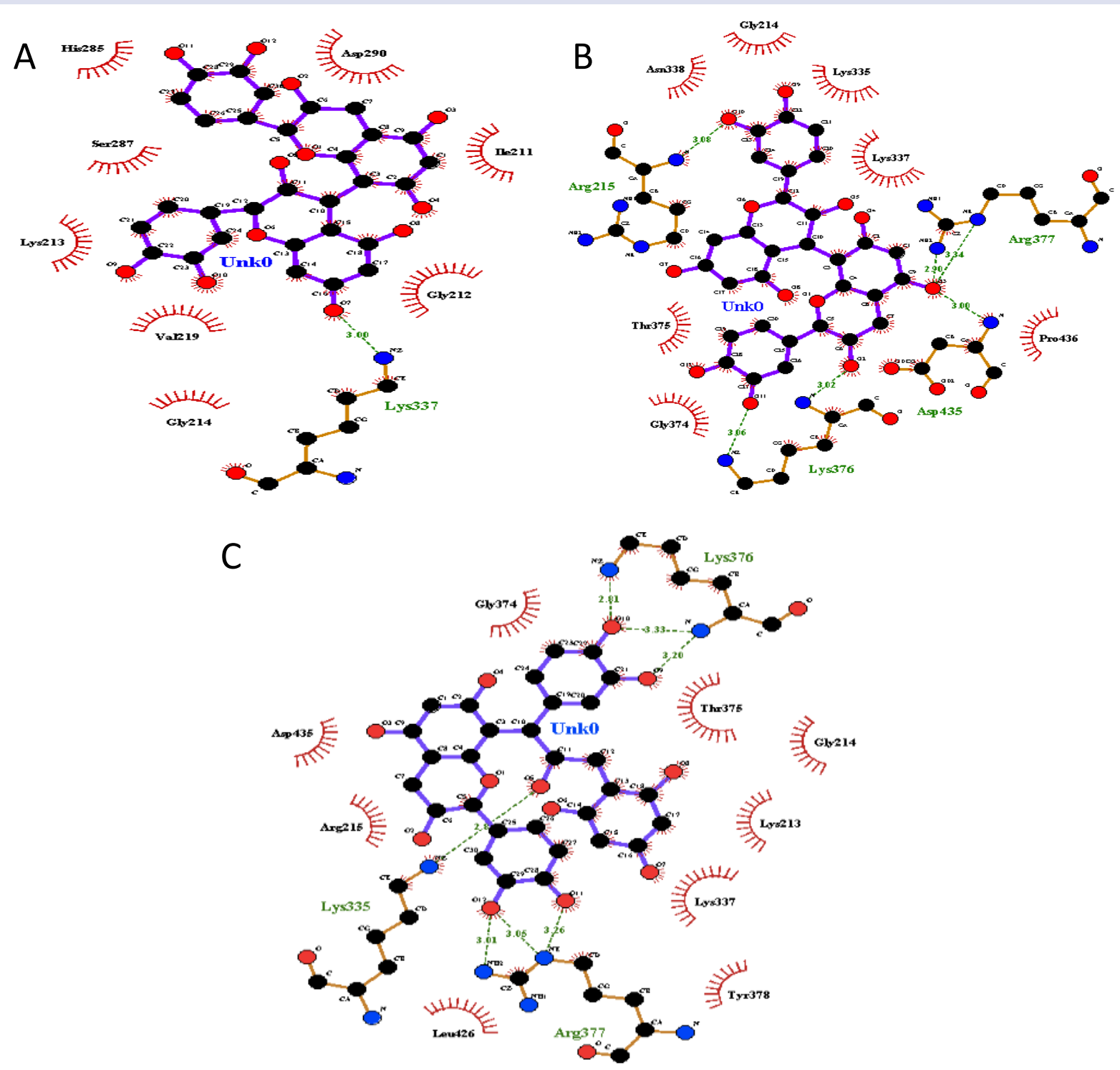

Figure 2: 2D interaction between substances and amino acid residues (A: procyanidin B3, B: procyanidin B1, C: gambiriin A1). 
distance with a grid box size of $40 \mathrm{x} 40 \mathrm{x} 40$. The grid center coordinate was $(x=14.129 ; y=67.092 ; z=5.249)$ (Figure 3 ).

From the results of the docking, the substances in the Gambir plant can be TGF $\beta R 1$ inhibitors. Three compounds from gambir such as catechin, epigallocatechin gallate and procyanidin B3 showed best binding affinity score $-9.4 ;-9.0$ and $-9.3 \mathrm{kcal} / \mathrm{mol}$ (Table 4 ).

From the analysis result of ligand-receptor, all substances were in the active site of TGFBR1 $(211 . .215,219,230,232,260,280,283,287,289$, $333,335,337,338,340,351,354,374 . .377)$, as well as the native ligand, which was a TGFBR-1 inhibitor (Naphthyridine). The high inhibitory activity of $(+)$-catechin can be caused by interaction similarity between native ligand, which was not seen in other substances, i.e. at 230, 232, $260,280,340,351$. The amino acid residual interactions of (+)-catechin, Procyanidin B3, and (+)-Epigallocatechin gallate were 13, 9, and 12, respectively (Table 5$)$. Seen from the amino acid interaction mapping between (+)-catechin ligand with the native ligand, the binding affinity value was inferior to native ligand due to several interactions that had no hydrogen bond (Figure 4).

\section{MTT assay}

Viability and Characterization of Cell lines A549 lung fibrosis used in the MTT test. The cytotoxicity activity of the ethanolic extract of Uncaria gambir (Hunter) Roxb. was carried out by using MTT assay with different concentration on A459 cell lines. Results of anticancer activity on A459 are shown in Table 6.

Antifibrosis inhibitors and agents, commonly fibroblasts in inflammatory conditions agents are used in management of tumor growth factors (e.g., vascular endothelial-derived growth factor, transforming growth factor beta (TGF $\beta$ ), hepatocyte growth factor, epidermal growth factor, and fibroblast growth factor. The ethanolic extract of Uncaria gambir (Hunter) Roxb. shows the concentration dependent inhibition. The ethanolic extract of Uncaria gambir (Hunter) Roxb was found to have strong inhibitory activity $\left(\mathrm{IC}_{50}\right.$ $19,255 \pm 1.08 \mu \mathrm{g} / \mathrm{ml})$ while, considering the standard drug cisplatin $(1,02121 \mathrm{E}-06 \pm 0.03 \mu \mathrm{g} / \mathrm{ml}$ ) (Figure 5) with $\mathrm{R} 0,9178$ and 0,9373 respectively. In consequence, the IC50 of ethanolic extract of Uncaria gambir (Hunter) Roxb extracts might be due to the presence of phenols, phenolic total.

Table 3: Interaction analysis by mapping amino acid residues.

\begin{tabular}{cccc|}
\hline Amino acid & Procyanidin B3 & Procyanidin B1 & Gambirin A1 \\
\hline Ile211 & $\sqrt{ }$ & - & - \\
Gly212 & $\sqrt{ }$ & - & - \\
Lys213 & $\sqrt{ }$ & - & $\sqrt{ }$ \\
Gly214 & $\sqrt{ }$ & $\sqrt{ }$ & $\sqrt{ }$ \\
Arg215 & - & $\sqrt{ }$ & $\sqrt{ }$ \\
Val219 & $\sqrt{ }$ & - & - \\
His285 & $\sqrt{ }$ & - & - \\
Ser287 & $\sqrt{ }$ & - & - \\
Asp290 & $\sqrt{ }$ & - & - \\
Lys335 & - & $\sqrt{ }$ & $\sqrt{ }$ \\
Lys337 & $\sqrt{ }$ & $\sqrt{ }$ & $\sqrt{ }$ \\
Asn338 & - & $\sqrt{ }$ & - \\
Gly374 & - & $\sqrt{ }$ & $\sqrt{ }$ \\
Thr375 & - & $\sqrt{ }$ & $\sqrt{ }$ \\
Lys376 & - & $\sqrt{ } *$ & $\sqrt{ }$ \\
Arg377 & - & - & $\sqrt{ }$ \\
Tyr378 & - & - & $\sqrt{ }$ \\
Leu426 & - & $\sqrt{ }$ & $\sqrt{ }$ \\
Asp435 & - & $\sqrt{ }$ & - \\
Pro436 & - & 11 & 12 \\
Total interaction & 9 & & \\
\hline
\end{tabular}

Residual analysis (*: hydrogen bond)

Table 4: Binding affinity score from docking gambir compounds with TGF- $\beta 1$.

\begin{tabular}{lll}
\hline No & Compounds & $\Delta \mathrm{G}(\mathrm{kcal} / \mathrm{mol})$ \\
\hline $\mathbf{1}$ & (+)-Catechin & $\mathbf{- 9 . 4}$ \\
$\mathbf{2}$ & Epigallocatechin gallate & $\mathbf{- 9 . 0}$ \\
3 & (+)-Epicatechin & -8.6 \\
4 & Gambiriin A1 & -8.4 \\
5 & Gambiriin A2 & -8.0 \\
6 & Gambiriin B1 & -8.4 \\
7 & Gambiriin B2 & -8.2 \\
8 & Gambiriin C & -8.5 \\
9 & Procyanidin B1 & -9.0 \\
$\mathbf{1 0}$ & Procyanidin B3 & $-\mathbf{9 . 3}$ \\
$\mathbf{1 1}$ & Native ligand & $\mathbf{9 . 7}$ \\
\hline
\end{tabular}



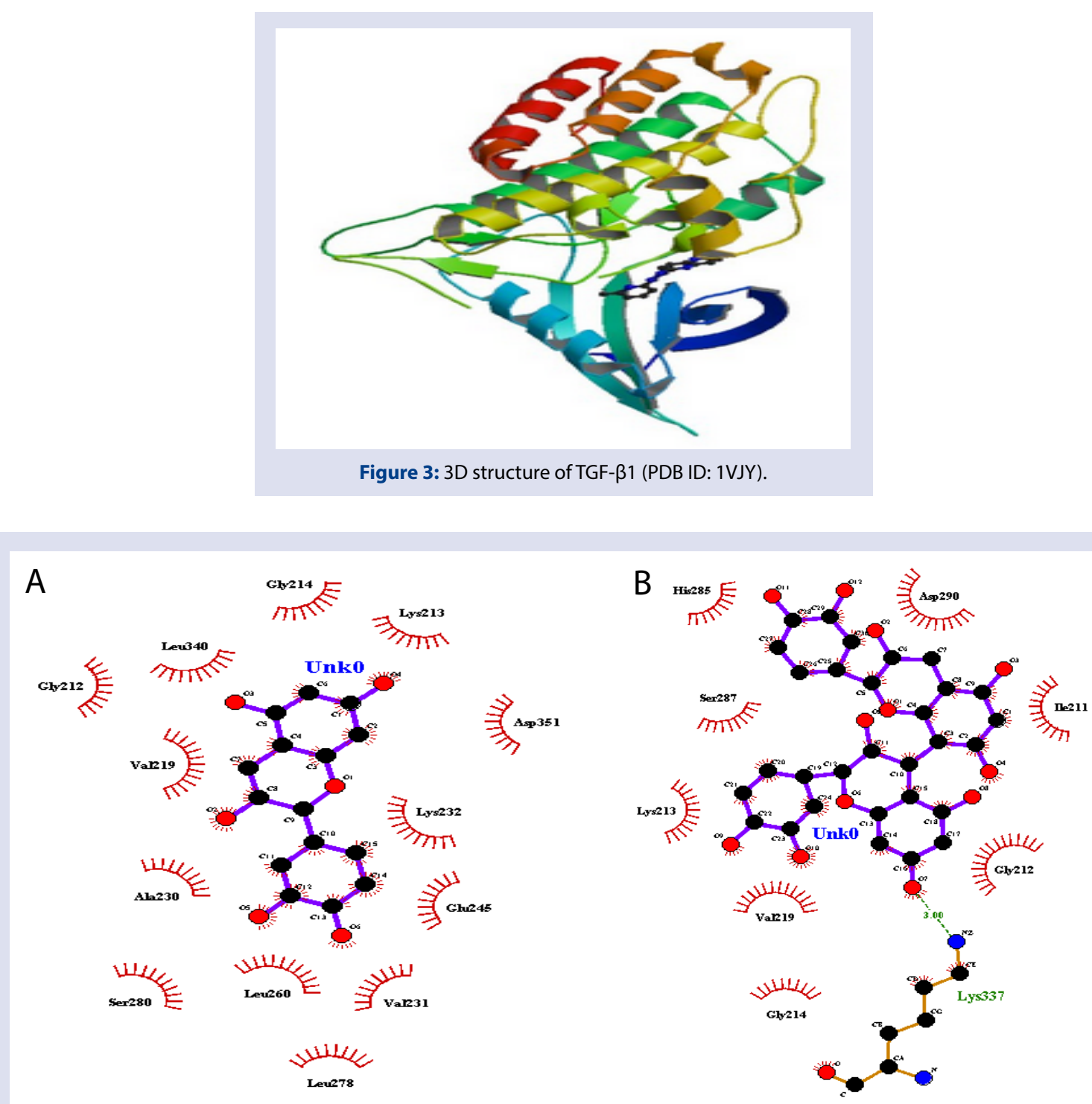

C

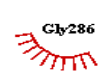$$
\text { D }
$$
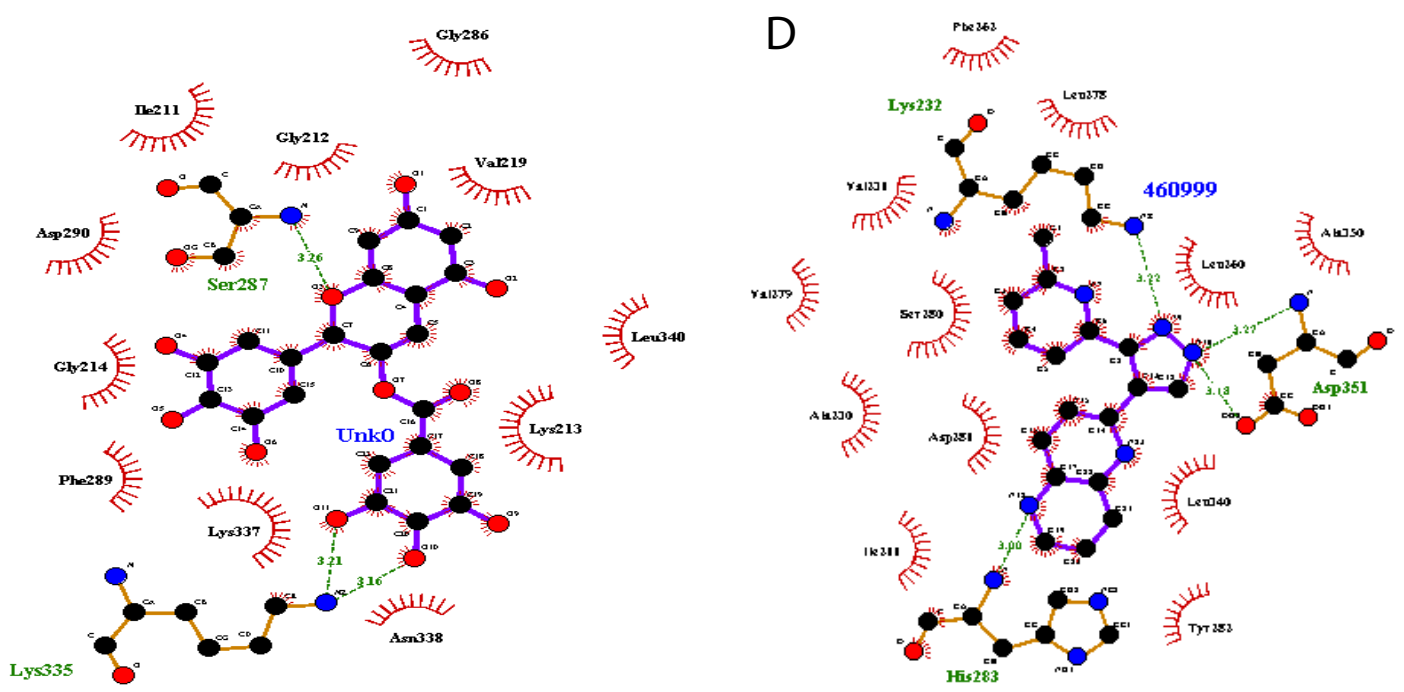

Figure 4: 2D interaction between substances with amino acid residues (A: catechin, B: procyanidin B3, C: epigallocatechin gallate, D: native ligand). 
Table 5: Binding affinity score from docking gambir compounds with TIMP-1.

\begin{tabular}{ccc}
\hline No & Compounds & $\Delta \mathrm{G}(\mathrm{kcal} / \mathrm{mol})$ \\
\hline 1 & (+)-Catechin & -8.4 \\
2 & Epigallocatechin gallate & -9.5 \\
3 & $(+)$-Epicatechin & -7.3 \\
4 & Gambiriin A1 & -8.4 \\
$\mathbf{5}$ & Gambiriin A2 & $-\mathbf{9 . 7}$ \\
$\mathbf{6}$ & Gambiriin B1 & $-\mathbf{1 0 . 0}$ \\
$\mathbf{7}$ & Gambiriin B2 & $-\mathbf{9 . 7}$ \\
8 & Gambiriin C & -9.5 \\
9 & Procyanidin B1 & -9.4 \\
10 & Procyanidin B3 & -9.2 \\
\hline
\end{tabular}

Table 6: IC50 value of ethanolic extract of Uncaria gambir (Hunter) Roxb with A549 cell line.

\begin{tabular}{|c|c|c|c|c|c|c|c|}
\hline \multirow{2}{*}{ Concentration } & \multirow{2}{*}{$\stackrel{\log }{\text { concentration }}$} & Absorbance & \%inhibition & Ic50 & Absorbance & \%inhibition & Ic50 \\
\hline & & \multicolumn{3}{|c|}{ Standart Cisplatin } & \multicolumn{3}{|c|}{ ethanolic extract of Uncaria gambir } \\
\hline 1,5625 & 0,19382002 & 0,159 & 77,69985975 & & 0,459 & - & \\
\hline 3,125 & 0,49485002 & 0,145 & 79,61664329 & & 0,624 & 12,4824684 & \\
\hline 6,25 & 0,79588001 & 0,125 & 82,42169238 & & 0,355 & - & \\
\hline 12,5 & 1,09691001 & 0,121 & 82,9827022 & $1,02121 \mathrm{E}-06 \pm$ & 0,321 & 54,9789621 & $19,255 \pm 1.08$ \\
\hline 50 & 1,69897000 & 0,100 & 86,02150538 & 0.03 & 0,266 & 62,6928471 & $\mu \mathrm{g} / \mathrm{ml}$ \\
\hline 100 & 2 & 0,101 & 85,8345021 & & 0,133 & 81,3464235 & \\
\hline \multirow[t]{2}{*}{200} & 2,30102999 & 0,121 & - & & 0,125 & 82,5151940 & \\
\hline & Control & 0,713 & & & 0,713 & & \\
\hline
\end{tabular}

$\mathrm{IC}_{50}$ value less than 100 is considered as an active extract with anticancer activity. As shown in Table 6, ethanolic extract of Uncaria gambir have $\mathrm{IC}_{50}$ value lower than $100 \mu \mathrm{g} / \mathrm{mL}$, that is assigned as active extract. ethanol extracts showed strong anticancer activity. Consistent and agree with the computational in silico molecular docking the substances in the Gambir plant can be TGF $\beta$ R1 inhibitors. Three compounds from gambir such as catechin, epigallocatechin gallate and procyanidin B3 showed best binding affinity score $-9.4 ;-9.0$ and $-9.3 \mathrm{kcal} / \mathrm{mol}$ respectively and compere with $\mathrm{IC}_{50}$ value of $19,255 \pm 1.08 \mu \mathrm{g} / \mathrm{ml}$. This result indicates that ethanol extract of Uncaria gambir potential to be developed as an anti fibrotic drug assessment, ethanol extract of Uncaria gambir presence of polyphenols $(56.4+6.47 \mathrm{mg}$ eq. QE/g Ext), demonstrated the greater anticancer activity than the other extract on A549 lung cancer cells.

\section{CONCLUSION}

Molecular docking simulation of gambir compounds to discover its anti-fibrotic activity has been done to explore its potential for inhibiting DNA transcription of NF- $\mathrm{kB}, \mathrm{TGF}-\beta 1$ receptors. Three compounds from gambir plant such as catechin, epigallocatechin gallate and procyanidin $\mathrm{B} 3$ showed best binding affinity score $-9.4 ;-9.0$ and -9.3 $\mathrm{kcal} / \mathrm{mol}$ respectively and compere with $\mathrm{IC}_{50}$ value of $19,255 \pm 1.08 \mu \mathrm{g} /$ $\mathrm{ml}$. This result indicates that ethanol extract of Uncaria gambir potential to be developed as an anti-fibrotic drug asessment, ethanol extract of Uncaria gambir presence of polyphenols $(56.4+6.47 \mathrm{mg}$ eq. QE/g Ext), demonstrated the greater anticancer activity than the other extract on A549 lung cancer cells.

\section{ACKNOWLEDGEMENT}

This research has been supported by Beasiswa Unggulan Dosen Indonesia Dalam Negeri (BUDI-DN) through the Ministry of Research,
Technology and Higher Education of the Republic of Indonesia (KEMRISTEKDIKTI), together with the Indonesia Endowment Fund for Education (LPDP).

\section{CONFLICTS OF INTEREST}

The authors declare no conflicts of interest.

\section{REFERENCES}

1. Meurer SK, Tihaa L, Lahme B, Gressner AM, Weiskirchen R. Identification of Endoglin in Rat Hepatic Stellate Cells. J Biol Chem. 2005;280(4):3078-87.

2. Dong C, Gongora R, Sosulski ML, Luo F, Sanchez CG. Regulation of transforming growth factor-beta1 (TGF- $\beta 1$ )-induced pro-fibrotic activities by circadian clock gene BMAL1. Respir Res. 2016;17(1):4.

3. Fan $\mathrm{X}$, Zhang $\mathrm{Q}$, Li S, Lv Y, Su H, Jiang H, et al. Attenuation of CCl4-Induced Hepatic Fibrosis in Mice by Vaccinating against TGF- $\beta 1$. Mukhopadhyay $P$, editor. PLoS One. 2013;8(12):e82190.

4. Hafez MM, Hamed SS, El-Khadragy MF, Hassan ZK, Al Rejaie SS, Sayed-Ahmed $\mathrm{MM}$, et al. Effect of ginseng extract on the TGF- $\beta 1$ signaling pathway in $\mathrm{CCl} 4$ induced liver fibrosis in rats. BMC Complement Altern Med. 2017;17(1):45.

5. Li JW-H, Vederas JC. Drug Discovery and Natural Products: End of an Era or an Endless Frontier? Science (80-). 2009;325(5937):161-5.

6. Dhalimi A. Permasalahan Gambir (Uncaria gambir L.) di Sumatera Barat dan Alternatif Pemecahannya. Perspektif. 2015;5(1):46-59.

7. Hussin $\mathrm{MH}$, Kassim MJ. The corrosion inhibition and adsorption behavior of Uncaria gambir extract on mild steel in $1 \mathrm{M} \mathrm{HCl}$. Mater Chem Phys. 2011;125(3):461-8.

8. Sri Ningsih. Efek hepatoprotektor gambir (Uncaria gambir (Hunter)Roxb.) dalam menghambat pembentukan kolagen dengan menekan TIMP-1 (Tissue inhibitor of metalloproteinase-1) in vivo. Universitas Indonesia; 2015.

9. Pranowo HD, Hetadi AKR. Pengantar Kimia Komputasi. Bandung: Penerbit Lubuk Agung; 2011.

10. Ferreira L, dos Santos R, Oliva G, Andricopulo A. Molecular Docking and Structure-Based Drug Design Strategies. Molecules. 2015;20(7):13384-421. 


\section{GRAPHICAL ABSTRACT}
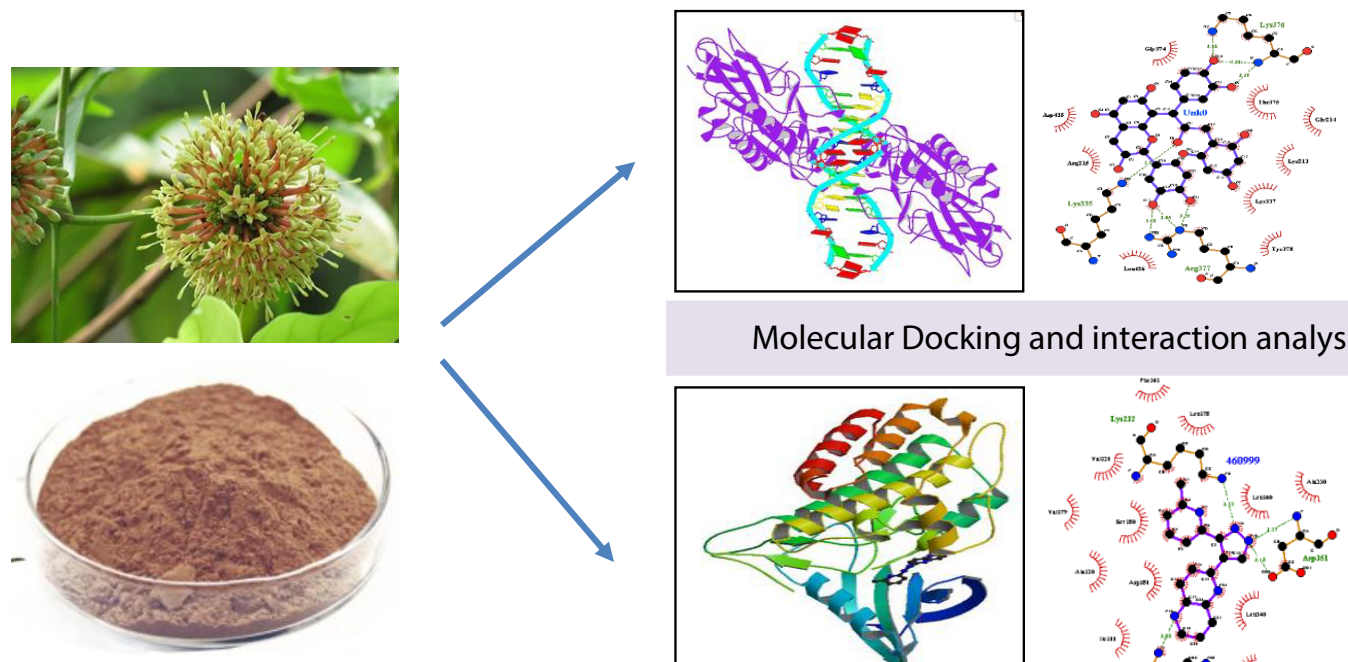

Molecular Docking and interaction analysis

IC50: $19,255 \pm 1.08 \mu \mathrm{g} / \mathrm{ml}$

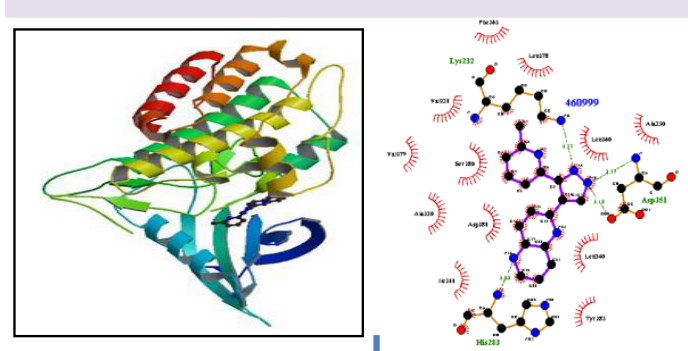

\begin{tabular}{|c|c|c|c|c|c|c|c|}
\hline \multirow{3}{*}{$\begin{array}{r}\text { Concentration } \\
1,5625\end{array}$} & \multirow{2}{*}{$\begin{array}{c}\text { Log } \\
\text { concentration }\end{array}$} & Absorbance & \%inhibition & Ic50 & \begin{tabular}{|l|l} 
Absorbance \\
\end{tabular} & \%inhibition & \multirow{2}{*}{$\frac{\text { Ic50 }}{\text { gambir }}$} \\
\hline & & \multicolumn{3}{|c|}{ Standart Cisplatin } & \multicolumn{2}{|c|}{ ethanolic extract of Uncaria gambir } & \\
\hline & 0,19382002 & 0,159 & \begin{tabular}{|l|l|}
77,69985975 \\
\end{tabular} & \multirow{8}{*}{$\begin{array}{l}1,02121 \mathrm{E}- \\
06 \pm 0.03\end{array}$} & 0,459 & - & \multirow{8}{*}{$\begin{array}{c}19,255 \pm \\
1.08 \\
\mu \mathrm{g} / \mathrm{ml}\end{array}$} \\
\hline 3,125 & 0,49485002 & 0,145 & 79,61664329 & & 0,624 & 12,4824684 & \\
\hline 6,25 & 0,79588001 & 0,125 & 82,42169238 & & 0,355 & - & \\
\hline 12,5 & 1,09691001 & 0,121 & 82,9827022 & & 0,321 & 54,9789621 & \\
\hline 50 & 1,69897000 & 0,100 & \begin{tabular}{ll|}
86,02150538 \\
\end{tabular} & & 0,266 & 62,6928471 & \\
\hline 100 & 2 & 0,101 & 85,8345021 & & 0,133 & 81,3464235 & \\
\hline \multirow[t]{2}{*}{200} & 2,30102999 & 0,121 & - & & 0,125 & 82,5151940 & \\
\hline & Control & 0,713 & & & 0,713 & & \\
\hline
\end{tabular}

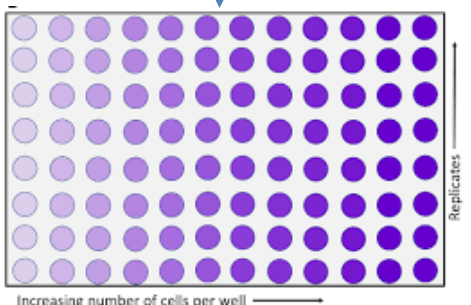

MTT Assay

\section{ABOUT AUTHORS}

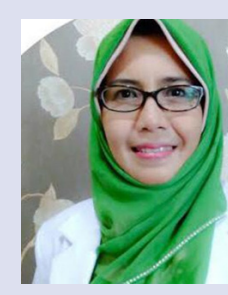

\section{Desdiani}

Doctoral Degree Student of Faculty of Medicine, University of Indonesia, and Vice Dean for Academic and Student Affairs Faculty of Medicine, University of Sultan Ageng Tirtayasa, Cilegon, Banten. Research interest: orthopedic, community medicine, herbal medicine.

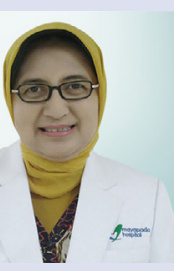

\section{Iris Rengganis}

Senior Lecturer of Departement Internal Medicine, Faculty of Medicine, University of Indonesia. Research interest: allergy and immunology and internal medicine.

\section{Samsuridjal Djauzi}

Senior Lecturer of Departement Internal Medicine, Faculty of Medicine, University of Indonesia. Research interest such as HIV/AIDS, hepatitis C, and immunology. 


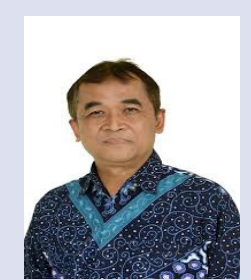

\section{Agus Setiyono}

Lecturer at Faculty of Veterinary Medicine IPB, Bogor. Research interest analytical chemistry and natural product chemistry in drug development.

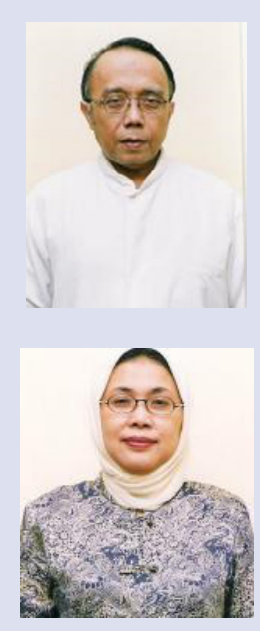

\section{Mohamad Sadikin}

Senior Lecturer at Department of Biochemistry and Molecular Biology, Faculty of Medicine, University of Indonesia. Research interest: antioxidative activity from herbal extracts, biochemical, proteasome, expression of hypoxia inducible factor-1 (HIF-1a).

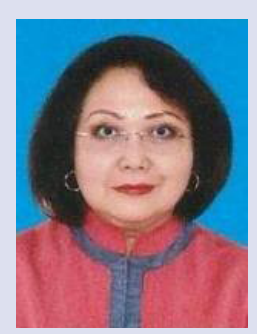

\section{Nuryati Chairani Siregar}

Senior Lecturer at Department Anatomical Pathology, Faculty of medicine, University of Indonesia. Research interest: immunohistochemical, mitochondrial DNA polymorphism, cytotoxicity activity, hepatocellular carcinoma.

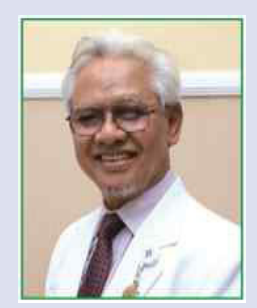

\section{Suradi}

Senior Lecturer at Department of Pulmonology and Respiratory Medicine, Faculty of medicine, Universitas Sebelas Maret, Central Java. Research interest: pulmonology and respiratory medicine.
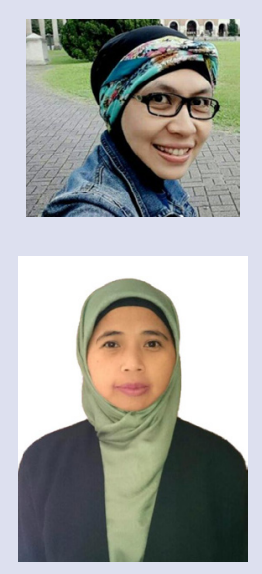

\section{Fadilah}

Senior Lecturer at Department of Medical Chemistry, Faculty of Medicine, Universitas Indonesia and Head of Department of Bioinformatics Core Facilities - IMERI. Research interest: bioinformatics, drug discovery and development from herbal compounds, phytochemical analysis, drug compounds synthesis and molecular modeling.

Cite this article: Desdiani D, Rengganis I, Djauzi S, Setiyono A, Sadikin M, Jusman SWA, et al. In Vitro Assay and Study Interaction of Uncaria gambir (Hunter) Roxb. as Anti-fibrotic Activity Against A549 Cell Line. Pharmacogn J. 2020;12(6):1232-40. 